\title{
Health and Its Discontents: Health Opinion Leaders' Social Media Discourses and Medicalization of Health ${ }^{*}$
}

\author{
Prof. Dr. Yasemin INCEOĞLU \\ Yrd. Doç. Dr. Burak ÖZÇETiN \\ Meltem GÖKMEN TOL \\ Saygın Vedat ALKURT
}

galatasaray üniversitesi, iletişim fakültesi yinceoglu@gsu.edu.tr akdeniz üniversitesi, iletişim fakültesi ozcetin@akdeniz.edu.tr gokmen.meltem@gmail.com yaşama dair vakıf, sayginalkurt@gmail.com

\begin{abstract}
Concerns regarding body and health colonize nearly all aspects of contemporary societies. Citizens are exposed to discourses disseminated from innumerable sources, on living a healthier, happier life and attaining a more desirable body. The common point for these discourses is their role in medicalization and individualization of health, i.e. approaching natural cycles of life as diseases and ignoring the social determinants of health. Health professionals, or "health opinion leaders", occupy a strategic and advantageous position in this process. Most recently, web 1.0 and web 2.0 environments, especially social media outlets come forward among these sources. Social media provides health opinion leaders with opportunities to continuous and easy opinion/idea dissemination, and to mutual interaction with followers. Definition and promotion of diseases and fear; lifestyles and habits; beauty; longevity; performance and personal development; and naturalness lie at the center

* The article is based on findings of Social Media Opinion Leadership Research supervised by Prof. Dr. Yasemin İnceoğlu with researchers Assist. Prof. Dr. Burak Özçetin, Meltem Gökmen and Saygın Vedat Alkurt. The project, coded 12.300.002, is funded by Galatasaray University Scientific Research Projects Fund. The project team would like to express their gratitude to Galatasaray University SRP Fund for their support and contribution / Makaleye kaynaklık eden Sosyal Medya Kanaat Önderliği Araştırması Prof. Dr. Yasemin İnceoğlu tarafından yürütülmüş ve Yrd. Doç. Dr. Burak Özçetin, Meltem Gökmen ve Saygın Vedat Alkurt projede araştırmacı olarak görev almıştır. 12.300.002 kodlu bu proje, Galatasaray Üniversitesi Bilimsel Araştırma Projeleri Fonu tarafından desteklenmiştir. Galatasaray Üniversitesi BAP Fonu'na destek ve katkılarından ötürü teşekkür ederiz.
\end{abstract}


of their discursive strategy. This article suggests that social media discourses of health professionals on health and body must be considered within the context of medicalization and commodification of health in contemporary societies, and within the context of neoliberal governmentality.

keywords: health opinion leaders, medicalization, governmentality, neoliberalism, discourse

\section{Résumé}

\section{La Santé et ses malaises: Le discours des leaders d'opinion sur la santé dans les médias sociaux et la médicalisations de la Santé}

Les soucis concernant la santé et le corps ont déjà monopolisés nos jours tous les sujets de la vie quotidienne Les citoyens sont en train de subir d'innombrables déclarations diffusées par des milliers de sources à propos d'une vie plus saine, plus heureuse et un corps plus désirable. Le point commun de ces discours est le role qu'ils jouent dans la médicalisation et l'individualisation de la santé (C'est-à-dire que les cycles naturels de la vie sont considérés comme des maladies et que les facteurs sociaux de la santé sont ignorés) Les professionnels de la santé ou encore les leader d'opinion ont dans cette démarche une position stratégique et avantageuse. Les technologies Web 1.0 et web 2.0 sont une des sources qui permettent la diffusion de ces messages a travers les réseaux sociaux d'une façon très rapide.. Les réseaux sociaux offrent facilement des possibilités d'interaction entre les leaders d'opinion de la santé et leurs abonnés, et de déclaration d'idées/d'opinion. Au cœur de leur stratégie discursive se trouvent la définition et la promotion des maladies et de la peur; des modes de vie et des habitudes; la beauté; la longévité de la vie; la performance et le développement personnel; et l'état d'être naturel. Cet article propose que les discours de médias sociaux de professionnels de la santé sur la santé et le corps doivent être considérés dans le cadre de la médicalisation et la marchandisation de la santé dans les sociétés contemporaines, tout en tenant compte de la gouvernementalité néolibérale.

mots-clés : les leaders d'opinion, médicalisation, gouvernementalité, néolibéralisme, discours 


\section{Özet}

\section{Sağlık ve Hoşnutsuzlukları: Sağlık Kanaat Önderlerinin Sosyal Medya Söylemleri ve Sağlığın Tıbbileştirilmesi}

Sağlık ve beden ile ilgili kaygılar günümüz toplumlarının neredeyse tüm alanlarını sömürgeleştirmiş durumdadır. Yurttaşlar daha sağlıklı, daha mutlu bir hayat yaşama ve daha arzu edilir bir bedene sahip olma üzerine sayısız kaynaktan yayılan söylemlere maruz kalmaktadırlar. Bu söylemlerin ortak noktası sağlığın tıbbileştirilmesine ve bireyselleştirilmesinde -yani yaşamın doğal döngülerine hastalık olarak yaklaşılması ve sağlığın toplumsal belirleyenlerinin göz ardı edilmesi-oynadıkları roldür. Sağlık profesyonelleri ya da "sağlık kanaat önderleri" bu süreçte stratejik ve avantajlı bir konum işgal etmektedirler. Son dönemlerde web 1.0 ve web 2.0 teknolojileri, özellikle de sosyal medya sağlık söyleminin yayıldı̆̆ı kaynaklardan biridir. Sosyal medya mecraları sağlık kanaat önderleri için kolay kanaat/fikir beyanı ve sağlık kanaat önderleri ile takipçileri arasında karşılıkı etkiletişim olanakları sunmaktadır. Bu figürlerin söylemsel stratejilerinin merkezinde şu öğelerin tanımlanması ve promosyonu yer alır: hastalık ve korku; yaşam tarzları ve alışkanlıklar; uzun yaşam; performans ve kişisel gelişim; doğallık. Bu çalışma sağlık profesyonellerinin sağlık ve beden söylemlerinin sağıĬın tıbbileştirilmesi ve metalaşması ve neoliberal yönetimsellik kavramları ile ilişkilendirerek ele alınması gerektiği vurgulamaktadır.

anahtar kelimeler: sağlık kanaat önderleri, tıbbileştirme, yönetimsellik, neoliberalizm, söylem 


\section{Introduction}

The medicalization and commodification of health are two significant aspects of contemporary life. In fact, although pointing to different phenomena, each with its own complex web of relations and determinants, these two aspects cannot be fully understood without showing their entwinement. This article questions the reflections of these two phenomena in Turkey by analyzing health discourse of health professionals (or, health opinion leaders) in Turkey. More specifically, the article will focus on social media performance of health professionals in Turkey, through the theoretical and methodological outlook provided by discourse theory and Critical Discourse Analysis.

The central themes of this study are medicalization, individualization and commodification of health. In recent decades, public services, including health and education, are increasingly becoming commoditized in Turkey. The wellbeing of consumer/citizens has become a huge and profitable economic sector within which numerous actors are struggling to occupy advantageous positions. The body has turned into a field of competing discourses and interests; colonized by medicine, cosmetics and lifestyle 'economies' and strategies. However, the colonization of the body by commercial interests is only a part of the story. This article argues that the health discourse disseminated by the health professionals in the social media must be thought within the context of 'governmentality' (Foucault 1991) and 'neoliberal governmentality'.

Studying health professionals in the new media channels is important for two reasons: first, especially in the last decade, we are witnessing emergence of a novel phenomenon which can be called "health opinion leaders", or "health celebrities". The symbolic-elites of health, with their professional authority, draw the line of distinction between healthy and unhealthy bodies; legitimate and illegitimate lifestyles; desirable and undesirable looks; harmful and useful diets, etc. These figures, including academics, doctors, dieticians and herbalists, through use of traditional (newspapers, TV shows, radio programs, magazines) and new media channels (web 1.0 and web 2.0 technologies) became important disseminators of health discourse in contemporary societies; which was a role undertaken almost exclusively by the state in the previous decades. Second, proliferation of new media use within the society changed the way people gathered health information. Several studies show that new media channels, especially the Internet, are increasingly being used for gathering relevant health information. Health opinion leaders struggle to occupy critical positions in this field, and to present themselves as reliable information sources.

Rather than solely confining within the limits of textual analysis of health opinion leaders' discourses, the article will problematize and elaborate the context within which these discourses are formed and disseminated. The discourses of health constructed and disseminated by health opinion 
leaders will be located within a wider framework; and related to the notion of governmentality in industrial and advanced liberal societies; and with phenomena such as reproduction of labor power, normalization strategies, culture of fear and consumption, and control and discipline.

\section{Discourse Theory, Critical Discourse Analysis and Health Discourse}

There are different approaches to discourse, yet all start out from the same idea: human behavior is always mediated by language, therefore meaningful. The aim is to explore and analyze this meaning and its conditions of emergence. Every social action or activity can be read as a 'text' pertaining to certain historical conditions within a certain web of relations. Within this context, discourse theory and Critical Discourse Analysis provides the researcher with invaluable theoretical and methodological framework for understanding the constructed and hierarchical nature of social reality. However, it must be stressed that discourse analysis is not a fixed method waiting to be applied to different cases irrespective of situatedness (social, political, economic, and institutional) of these texts. Rather, it is an approach, a way of tackling with the question of the relationship between texts, meanings and social reality.

The basic idea behind discourse analysis is that power relations in society can be read through an analysis of the hierarchical ordering of the semiotic domain. It is through an ongoing and asymmetric struggle that meanings are continuously being negotiated, change, fixated, and renegotiated. Social classes, minority groups, interest groups, governments, etc. are the main parties of this process. The definition of social reality keeps changing in line with the struggle of power at micro and macro levels. Discourse theory traces the dynamics of this balance through deconstructing this struggle.

Discourse analysis focuses on the texts, in a wider sense of the term. Texts, which construct and reflect particular aspects of reality in a partial and particular way, can be newspaper articles, pictures, novels, interview transcripts, poems, field notes, or in our case, tweets. Discourse can be defined as "a patterned system of texts, messages, dialogue or conversation" which may be "rule-governed and highly structured, or ad hoc and context-bound" (Lupton 1992:145). A discourse can be defined as "a system of statements which constructs an object" (Parker 1992:3).

Discourse, and discursive authority draws the line between what can be said and talked about within a given socio-historical situation. It provides a set of possible and legitimate statements about a given area, and "organizes and gives structure to the manner in which a particular topic, object, process is to be talked about" (Kress 1989:7); it determines "who can speak, when and with what authority; and, conversely, who cannot" (Cheek 2004:1142). Discourse classifies, divides, systematizes, and defines the rules of classification (Foucault 2002:41). 
Discourse analysis does not confine itself within the limits of semiotic analysis of texts. Thus it is not a textual analysis per se. More than that, discourse analysis must respond to questions pertaining to production and dissemination of discourse, and conditions of possibility of the texts and statements. By conditions of possibility, we, by no means propose a deterministic schema which unmasks the 'real', 'hidden' mechanisms that guide and determine the content of the texts. Discourse analysis, as proposed in this study, consider production of meaning, texts and statements as irreducible aspects of material social processes. Discourse analysis problematizes the intricate and dialectical relationships between semiosis and other elements of social practices (Fairclough 2001:123). Discourse analysis "is concerned with the way in which texts themselves have been constructed in terms of their social and historical 'situatedness'" (Cheek 2004).

Central questions for discourse analysis are: 'Why was this said, and not that? Why these words, and where do the connotations of the words fit with different ways of talking about the world?' (Parker 1992:5). But, locating discourses to social and historical contexts also brings the question of disseminators of discourse to the fore. So, in addition to what is said, discourse analysis also questions the "who" (agents) of discourses. As it has been aptly stated by van Dijk (1989:21) Critical Discourse Analysis investigates: "Who can say or write what to whom in what situations? Who has access to the various forms or genres of discourse or to the means of its reproduction?" The production of mode of articulation of discourse is governed by "symbolic elites" such as "journalists, writers, artists, directors, academics, and other groups that exercise power on the basis of "symbolic capital." By using their privileged position (mostly taking its source from access to scientific knowledge or expertise), the symbolic elites act as "the manufacturer of public knowledge, beliefs, attitudes, norms, values, morals, and ideologies. Hence their symbolic power is also a form of ideological power" (Van Dijk 1989:22). For our case, the symbolic elites are health opinion leaders in the social media.

Discourse analysis can provide invaluable insights about, and can shed light to discourses on health and health related issues (body, lifestyle, beauty etc.). Lupton (1992:146) lists areas of research that may be relevant to discourse analysis of health issues as such:

- the interpersonal communication process between doctors and patients

- in-depth interviews about lay health beliefs

- conversations between lay people about health risks and issues

- government-sponsored health promotion messages

- health information in the mass entertainment and news media

- medical and public health journals and textbooks

- official texts (such as government health policy documents) 
This article problematizes discourses of health produced by symbolic elites of the "health field". ${ }^{1}$ Robertson (1998:155) notes that discourses on health come into and go out of fashion, but not arbitrarily. Discourses on health are deeply related with, or conditioned by the prevailing social, political and economic context within which they are produced. They give us clues about cultural, ideological and political codes of the age we live in. They tell us much about the conceptions and ideas regarding ideal and legitimate lifestyles; ruly and unruly behaviors; consumption patterns; reproduction of social and cultural hierarchies; and ideal citizenship. Discourses on health are also located at the intersection point of various professional and sectorial interests. So, discourses on health must be analyzed with taking wider political and socioeconomic phenomena into consideration.

\section{Ruly and Unruly Bodies}

The abnormal, as ab-normal, comes after the definition of the normal, it is its logical negation. However, it is the historical anteriority of the future abnormal which gives rise to a normative intention.... Consequently it is not paradoxical to say that the abnormal, while logically second, is existentially first. (Canguilhem 1991:243)

Social constructionism in sociology of medicine insists on the embeddedness of medicine in relations of power and domination (Lupton 2003:12). Within this strand of thought, subjects and expert knowledge pertaining to human body and health is deeply interwoven with wider social, cultural, economic and political structures and relations. So 'diseases' can no longer be regarded as natural events which emerge outside the language which they are described: "a disease entity is the product of medical discourses which in turn reflect the dominant mode of thinking (the episteme in Foucault's terminology) within a society" (Turner 1995:11). It was no other than Friedrich Nietzsche who pointed to the relationship between medicine and social power. In Gay Science, Nietzsche noted that "there is no health as such" but "innumerable healths of the body": "It is necessary to know the aim, the horizon, the powers, the impulses, the errors, and especially the ideals and fantasies of the soul, in order to determine what health implies even for the body" (Nietzsche 2001:1167). His view on normalization of body as a new pattern of power and control in modern societies, and attempt to reveal the professional interest behind medical discourse was followed by Michel Foucault. Against the tradition which treats knowledge as panacea to detriments of power, Foucault (1977:27-8) introduced a novel approach which proposed that power produces knowledge, "that power

1 We use the term "field" strictly in the Bourdieuan meaning of the term: as a space of conflict and competition "in which participants vie to establish monopoly over the species of capital effective in it -cultural authority in the artistic field, scientific authority in the scientific field, sacerdotal authority in the religious field, and so forth- and the power to decree the hierarchy and "conversion rates" between all forms of authority in the field of power" (Wacquant 1992: 17-8). 
and knowledge directly imply one another; that there is no power relation without the correlative constitution of a field of knowledge, nor any knowledge that does not presuppose and constitute at the same time power relations."

The emergence of scientific medicine as a separate discipline and expertise, was deeply related with rationalization of society through scientific categories (Turner 1995:206). The distinction between healthy and unhealthy bodies, and definitions of sickness was a part of containing and policing modern societies. Foucault noted the "explosion of numerous and diverse techniques for achieving the subjugation of bodies and the control of populations" marked "the beginning of an era of bio-power (Foucault 1978:140).

The rationalization of society and growth of the discipline pointed to the rise of a new governmental rationality, which is called 'governmentality' -a pseudonym introduced by Foucault. The main idea behind governmentality was that power is not only repressive, constraining and inhibitive; but also productive. In other words, power cannot be understood solely in negative terms; rather, it plays a positive role in production of forms of knowledge and subjectivity. Governmental technologies of the self are productive because they contributed to making of individuals "as a self with certain bodily habits and ways of conduct and as a self with a certain knowledge of itself and of its freedoms and responsibilities" (Thanem 2009:62). Foucault (1982:777-8) aimed to reveal the historical processes through which human beings are made subjects through three modes of objectification: i. modes of inquiry which try to give themselves the status of sciences; ii. "dividing practices"; and iii. the way a human being turns himself into a subject.

Governmentality involved the government of mentality and of the body. It targeted the way we think and take care of our bodies (Rose 1993; Thanem 2009:61). The control over the body has been sustained through systematization of knowledge and institutionalization of power. First, this implied the birth of new sciences such as biology, pedagogy, demography, criminology, psychiatry and so forth. Systematization and rationalization of knowledge was also entangled with birth of modern institutions, such as prison, hospital, school or asylum (Turner 2002:180), which played their parts in defining "normality" (Canguilhem 1991:238). Governmentality aimed at the extension of principles of calculation, prediction, efficiency and reliability to all spheres of life: economic, social, and political. ${ }^{2}$ It brought further specialization, examination, formalization and classification of every aspect of human life and its populations.

2 Colonization of life by (instrumental) rationality has been a recurrent theme criticized by several schools of thought. Critical Theory (Horkheimer and Adorno 2002) analyzed the irrational within the rational; Ritzer put forward McDonalization thesis -which is also relevant for our inquiry(Ritzer 2011); and Bauman (2000) pointed at the relationship between the Holocaust and modernity. 
Starting in the seventeenth century, anatomo-politics and bio-politics were two basic forms of ordering and disciplining individuals and populations. Anatomo-politics defined "how one may have a hold over others' bodies" (Foucault 1977:138) and centered on the body as a machine: "its disciplining, the optimization of its capabilities, the extortion of its forces, the parallel increase of its usefulness and its docility, its integration into systems of efficient and economic controls". Bio-politics "focused on the species body, the body imbued with the mechanics of life and serving as the basis of the biological processes: propagation, births and mortality, the level of health, life expectancy and longevity, (Foucault 1978:139). In bio-politics the object of governance and power is life itself (Dillon 2007:45). It would not be an exaggeration to say that the birth of medicine and medical practice was located at the heart of this process.

Governmental rationality did not appear out of thin air. The norms related with it (calculation, prediction, reliability and efficiency) are deeply rooted in, and fundamental to industrial capitalist development. The conditions of possibility of bio-politics must be sought in conditions of existence of capitalist economy. Market economy, which transformed every aspect of ancien regime also transformed the power (Gambetti 2012:3). It introduced a new relation with time and work by the division and supervision of labor (Thompson 1993:394). Turner (2002:192) noted that systematization and rationalization of life, body and work under industrial capitalism found its expression in ordering of dietary tables "aimed at forms of consumption which were regarded as 'irrational' threats to health, especially where overconsumption was associated with obesity and alcoholism."

The paternalistic, or "pastoral" (Foucault 1981), concern for the health of the individual basically aimed at forging productive workers, equipped with perfect self-discipline, exuding "health, energy and vitality". Capitalist workplace has been a space in which, through various discipline mechanisms, "unruly private bodies were transformed into a disciplined working cog" (Holliday and Thompson 2001:123). The workplace, under capitalist economic relations, was reconceptualized as a setting where specific notions of healthy and unhealthy bodies, and legitimate and illegitimate lifestyles were disseminated (McGillivray 2005a:130). Workplaces resembled "corporeal garages" in which the body is molded, directed, disciplined, punished or rewarded for facing hardships of rigorous working conditions (McGillivray 2005b:317).

Irving Kenneth Zola (1972:487) noted that medicine, in modern societies has become a major institution of social control, "nudging aside, if nor incorporating, the more traditional institutions of religion and law." For Zola, this has been accomplished through "medicalizing" much of daily living and locating medicine (and labels 'healthy' and 'ill') at the center of human existence. For Zola, medicalization of society comprises four concrete processes: 
- the expansion of what in life is deemed relevant to the good practice of medicine, which implied increased intervention to and involvement with the conditions that make people ill, i.e. taking preventive measures before the diseases process starts.

- the retention of absolute control over certain technical procedures, such as the right to do surgery and prescribe drugs.

- the retention of near absolute access to certain 'taboo' areas, which points to "medicine's almost exclusive license to examine and treat that most personal of individual possessions -the inner workings of our bodies and minds."

- the expansion of what in medicine is deemed relevant to the good practice of life, which refers to use of medical rhetoric (such as 'healthy' to define a sound economy) in the arguments to advance any cause.

Illich (1976:32) notes that medicine "discovers" new disorders and ascribes these disorders to concrete individuals". In this process of medicalization of health, the authority and control of health professionals over society is consolidated as such:

The emergence of a conglomerate health profession has rendered the patient role infinitely elastic. The doctor's certification of the sick has been replaced by the bureaucratic presumption of the health manager who arranges people according to degrees and categories of therapeutic need, and medical authority now extends to supervised health care, early detection, preventive therapies, and increasingly, treatment of the incurable. Previously modern medicine controlled only a limited market; now this market has lost all boundaries. Unsick people have come to depend on professional care for the sake of their future health. The result is a morbid society that demands universal medicalization and a medical establishment that certifies universal morbidity (1976:42).

In the twentieth century, a new form of governmentality has emerged in the Western world with the welfare state's excessive involvement in social and economic spheres through social security instruments. Monitoring and protecting public health was one of the biggest priorities of the welfare state. The "risk management" measures implied a new preventive paradigm in health policy -eliminating the diseases before they appear through targeting the conditions that cause emergence of diseases. These measures are called "inclusive technologies of government" by Rose (1993:293), which meant further rationalization of health policies and management of body (Delibaş 2013:106).

Since the Welfare state was excessively occupied with anatomo- and biopolitics, "the judges of normality" were present everywhere (Foucault 1977:304). The interest in bodies and lifestyles of individuals was not a concern only for the Welfare state; private companies, such as Ford Motor Company (with Sociology 
Department) were also developing programs to monitor and regulate the lifestyles and private lives of their workers for increasing productivity (McGillivray 2005a:129). The role played by private companies, however, increased in postWelfare neoliberal setting.

\section{Neoliberal Governmentality, Health and Medicine}

The neoliberal restructuring of the state following the fall of the Welfare regime brought radical changes in social security system and basic public services such as health and education. The framework of the new paradigm in public services including health has been determined by commodification, privatization and marketization of medicine (Ataay 2006; McIntyre and Mooney 2007:6). Turkey was not an exception. Items and services related with health, which were perceived to be public goods, gradually become commodities exchanged in the market. Ercan (2013:28) notes that, in Turkey, the health sector is being transformed in line with requirements and demands of free flow and accumulation of capital; and commodification of the health field requires transformation of health professionals into waged-labor, in other words, commodification of health labor force. So, transformation of health also implies a transformation of the medical profession itself.

Various aspects of medicalization and commodification of health have been handled by several critical commentators. With references to his personal experiences, Elliott (2010) points how the interests of big medical corporations, and pharmaceutical industry represented the "dark side" of medicine, and how the forces of market, with their endless lust for profit, endangered the health of millions, and transformed doctors into profit seeking, immoral technicians. Mooney, Corburn and Corburn, and Mclntyre (Coburn and Coburn 2007; Mclntyre and Mooney 2007; Mooney 2012) showed how worldwide neoliberal transformations are creating inequalities in access to basic health services, which has devastating human costs. In her research on transformation of health sector in Turkey, Kart (2013) presents the alienating effects of performance based salary system ${ }^{3}$ on physicians. Angell (2008) has noted that over the past two decades the pharmaceutical companies has gained unprecedented control over the evaluation and assessment of their own products; and Terzi (2013) showed how academics and "scientific" journals can manipulate findings of researches sponsored by pharmaceutical industry. The new governmental rationality, neoliberal governmentality and discourses on health can only be fully comprehended through reading it against such a background.

Following Rose (1993) we propose that the notion of governmentality still has a relevance for contemporary societies, since it suggests alternative ways of

3 The system has been explained by Recep Akdağ, former Minister of Health, as such: "In this system the more physician records and examines patients, the more she will earn" see Kart, 2013. 
thinking about the activity of politics. The forms of power that subject and master us rely on a multiplicity of interlocking apparatuses for the programming of different dimensions of life. For Rose, the contemporary government mentality, or neoliberal governmentality aims at "the enhancement of the powers of the client as customer":

This new specification finds its locus of support not in the failure of welfare but in the success of welfare and its associated experts in implanting norms of health, education and the like into citizens. Thus social insurance, as a principle of solidarity, gives way to a kind of privatization of risk management -in which the citizen adds to his or her obligations the need to adopt a calculative and prudent personal relations to risk and danger. And social work, as a means of civilization under tutelage, gives way to the private counselor, the self-help manual and the telephone help line, as practices whereby each individual binds themselves to expert advice as a matter of their own freedom.... To analyse them requires an investigation of the 'making up' of the modern citizen as an active agent in his or her government. (Rose 1993:296)

In neoliberal governmentality, managerialism cuts into people's everyday lives in a profound manner and this is done through personalization of risk and making of entrepreneurial individual who takes the responsibility of taking care of herself. The free individual are supposedly empowered to make their own choices and decisions, as it has been suggested in many self-help and selfimprovement manuals (Thanem 2009:61). Self-management of risk is closely tied up to major socioeconomic transformations in contemporary capitalism; to principles of deregulation, privatization, commodification all aspects of life, and market growth. On other words, it is deeply related to offloading responsibility from state to private individuals (McGillivray 2005a:130).

Neoliberal governmentality puts special emphasis on individual freedom; however, Thanem (2009) argues that this peculiar freedom is restricted to choosing what is expected of you. The principles of this new governmental rationality can be traced in the new health discourse and campaigns, which are characterized by stress on individuals, self-help, self-interest, success and personal wellbeing. The guiding principle of new health campaigns are no longer the self-denial; but the "pleasure", "fun" and "happiness" of having a healthier life and body. Fruits of a hedonistic consumer culture take the place of asceticism (Thanem 2009:68). By Baudrillard's (Baudrillard 1998:129) words body emerges as "the finest, most precious and dazzling object of the consumer package". With the "hygienic, dietetic, therapeutic cult surrounding it"; with "the obsession with youth, elegance, virility/femininity, treatments and regimes, and the sacrificial practices attaching to it" the body becomes an object of salvation (Baudrillard 1998:129). The neoliberal governmentality oscillates between hedonistic selfinterest and responsibilities of the individual citizen-consumer. Neoliberal subject of consumption is epitomized by the sarcastic saying of Munck, "I shop therefore I am" (2005:65). 
Castel notes that (1991:281) the new strategy of governmentality dissolved the notion of a subject or a concrete individual, and put in its place a combinatory of factors, the factors of risk. The transition from the concept of dangerousness to risk is what characterized governmental rationality in advanced liberalism. It is through this transition that the direct face-to-face relationship between the carer and the cared, the helper and the helped, the professional and the client was renounced. The essential component of intervention resides "in the establishing of flows of population based on the collation of range of abstract factors deemed liable to produce risk" (Castel 1991:281). For instance, in psychiatric medicine, while dangerousness "connoted an immanent quality of the subject", "in contrast, the notion or risk, although also acknowledging potentiality, is calculated through systematic statistical correlations and probabilities based on populations rather than the close observation of individuals" (Lupton 1999:94). The transition from dangerousness to risk has immediate political implications. The myth of eradication of risk gives birth to "a grandiose technocratic rationalizing dream of absolute control of the accidental", which constructs a mass of new risks and many new risks for further preventive interventions: "thus, a vast hygienist utopia plays on the alternate registers of fear and security, inducing a delirium of rationality, an absolute reign of calculative reason and no less absolute prerogative of its agents, planners, and technocrats, administrators of happiness for a life to which nothing happens" (Castel 1991:289).

Definition of risk, risk factors and being prepared for future risks dominates the discourse on health. Accordingly, we are living in an age of risks and uncertainty in which insecurity and fear are important motives behind our behaviors (Delibaş 2013). The defining feature of this "culture of fear" is "the belief that humanity is confronted by powerful destructive forces that threaten our everyday existence" (Furedi 2002:vii). The culture of fear is empowered by a paradox: fear shapes our apprehension of social reality, and begets endless series of preventive measures -a culture of control (Garland 2001). However, the preventive measures, rather than being a remedy to our fear, instigate it: "people who worry about their food actually likely to conclude that they are ill... the healthier we are, the more likely we are to define ourselves as ill" (Furedi 2002:xi). The culture of fear begets a culture of warnings, which are becoming more and more pervasive everyday:

I would like to get through a day without being assaulted by warnings. I find this barrage of dire information intrusive, pervasive, and depressing.... the signs, newspaper articles, radio reports, and labels tell me to "watch out." They let me know that life is dangerous. It's almost foolhardy to be in the sun, to be in a car, or to take food (poison?) from a supermarket shelf. Do I buy margarine or butter, knowing, as I have learned, that both are bad? (Reinharz 1997:477).

The pervasiveness of warnings, for Reinharz (1997:483) has four roots: 1) the increased emphasis on litigation in our society, 2) the medicalization of everyday life, 3) the emergence of political advocacy around illnesses and 
social problems, and 4) respect for science. Fear pertaining to health issues has been labeled as "media health scares" by Seale (2002:70), which has two broad areas: first, "the stories about harmful substances, practices and features of the environment that threaten health and safety"; and second, the "stories about people who are held responsible for damage to health and safety through evil, incompetent or thoughtless behaviour." Studies on risk and fear culture in Turkey, affirms this overall trend. For instance, a recent research analyzing news items showed us that the use of the words "danger", "risk", "disaster", and "fear" has considerably increased (nearly three times) in the last decade. 4 Another study (Atabek, Atabek, and Bilge 2013) points out that in the last decade the news discourse on health is becoming increasingly sensational. The discourse of the health professionals, as we will see below, is highly dominated by concerns on current and future risks that the "client-patient" faces and necessary preventive measures to be taken. The health opinion leader acts as a warning machine pointing at current and future risks regarding health and integrity of body.

\section{Health Professionals' Discourses in the Social Media}

Max Weber urged us to see the link between the interests of experts, professional groups, and intellectuals in constitution and dissemination of formal rationality and scientific knowledge. Accordingly, "the rise of legal rationality, theological systematization, formal musical notation and scientific reasoning was the outcome of both the logic embedded in these forms of discourse and the professional and class interests of lawyers, theologians, musicians and scientists" (Turner 2002:181). Expert knowledge and experts themselves, then, play a crucial role in making and dissemination of discourses. Modern societies are somewhat characterized by prevalence of expert knowledge over informal lay knowledge: "hence, technologies of self are often construed in terms of powerful systems of expert knowledge which provide information and guidelines to help individuals learn how to live and master themselves" (Thanem 2009:62). This argument gains much weight when medical discourse is questioned. Medical knowledge and expertise owes its authority to its ability to exclude and marginalize other ways of thinking about diseases, human body, health and health care practices (Cheek, 2004: 1143).

Media and health professionals' media presence play a foundational role in dissemination of discourses on health (Yüksel et al. 2014:60-64). Neuendorf (1990) notes that in addition to other individuals, experts, health institutions; news, documentary and entertainment media are other crucial health information sources for individuals. In dissemination of health information "opinion leaders" (Katz and Lazarsfeld 1956), or "thought leaders" (Elliott 2010) play a crucial

4 Bekir Ağırdır, "Endişeleri korku politikalarına çevirmek", http://t24.com.tr/yazarlar/bekir-agirdir/ endiseleri-korku-politikalarina-cevirmek,5898. 
role (Çınarlı 2008:141). Recently a new channel is gaining prevalence in health communication: the Internet and social network sites; and within these channels, a new opinion leader profile is emerging.

Internet is increasingly becoming an important source for individuals seeking information regarding health issues (complaints, symptoms, drugs, nutrition and fitness). Quick and easy access to information is one of the reasons behind using internet as an information source. With increased access, the Internet has evolved into a gigantic resource for those seeking health information. ${ }^{5}$ As early as in 2007, a poll has noted that 160 million Americans were using the Internet to find health related information. More than getting health related information, there are some researches pointing out that for some, the Internet is used also as a diagnostic tool. According to Health Online 2013 Research by Pew Research Center, 35\% of American adults stated that they have gone online to figure out their (or someone else's) medical condition and possible treatments. The research classifies these people as "online diagnosers". Regarding the accuracy of their initial online diagnosis, $41 \%$ of online diagnosers say that a medical professional confirmed their diagnosis, while $18 \%$ say the medical professional did not agree. $35 \%$ say that they have not visited a professional. 6

A recent study points out that nearly $79 \%$ of internet users in Turkey use the Internet as a source for health related information. ${ }^{7}$ However, it seems that the respondents use the Internet as a supplementary, rather than primary source of health related information, since $60 \%$ of respondents say that they directly go to hospital. Approximately one third of the Internet users use the Internet for health purposes twice or three times a week. $90 \%$ of users use the Internet for "health matters and diseases"; $56 \%$ for information regarding drugs; $48 \%$ for health services; and $44 \%$ for information about medical professionals. Search engines (75\% of the users) are the most popular sites for seeking health information; followed by health forums $(60 \%)$; direct questions to medical professionals (47\%); blogs (24\%) and finally Facebook and Twitter $(9 \%)$. All these data show us that the Internet has become a significant source for gathering health information in Turkey.

Increased Internet access to health information, and merge of social networks and health concerns have important consequences and implications pertaining to the relationship between medical professionals and patients

5 "Internet Access for Health Information and Advice", https://cahps.ahrq.gov/quality-improvement/improvement-guide/browse-interventions/Access/Internet-Access_Health-Info/index.html last accessed on 15 May 2014.

6 "Health Online 2013", http://www.pewinternet.org/2013/01/15/health-online-2013/last accessed on 15 May 2014.

7 "Türkiye'de Internetin Sağılk Amaçlı Kullanımı" (Use of the Internet for Health Purposes in Turkey), Social Touch, http://www.socialtouch.com.tr/\%E2\%9E\%A8-turkiyede-internetin-saglikamacli-kullanimi/ last accessed on 15 May 2014. 
(Powell, Darvell, and Gray 2003:74). Bottles (2009:22) notes that, "social network sites are changing the way patients and providers cope with health care concerns." Only on Yahoo, there are 178,000 health care sites, and many of these groups have thousands of active members (Bottles 2009:22). There are innumerable Internet health sources, which makes reaching relevant and reliable information an overwhelming task. The Pew survey underlines that many users do not follow recommended guidelines for checking the reliability and timeliness of information. Many users hardly ever pay attention to the date and source of information and may easily be misguided and manipulated. ${ }^{8}$ In this new environment, the health professional must construct and present herself as a reliable, reputable, and popular figure. Within the market of health professionals, the actors compete for increasing their ratings; Google hits; followers and friends. Transformation of medical professional into a popular figure is a part of commodification of health. But at the same time,

[The Internet is] changing the balance of knowledge between healthcare professionals and the public, empowering patients to become more involved in healthcare decision-making and contributing to the deprofessionalization of medicine. The professional power of medicine is being challenged by the public availability of specialist knowledge, and by improved access to information on alternative approaches to healthcare, healthcare performance statistics, and consumer rights. (Powell et al. 2003:75)

Thus, new media channels have transforming effects on medical profession and discourse. This is why detailed analysis of various aspects of medical professionals' new media performance is necessary for understanding current state of health discourse in Turkey. Studying social media networks are specifically important, since interaction is possible. Also, platforms such as Twitter provide opinion leaders with channels to share their ideas and statements pertaining to health issues in an easy, prompt, and brief manner.

For elaborating the health opinion leaders' discourse on health and body in social networks, we have followed the most popular (highest number of followers and Tweets; regular Tweeting) 47 health professionals (academics, medical doctors, dieticians and herbalists) in Twitter for one month. We have analyzed the health discourses and discursive strategies of professionals under these thematic headlines:

- defining and promoting diseases and fear

- defining and promoting lifestyles and habits

- defining and promoting beauty

- defining and promoting longevity

- defining and promoting performance and personal development

- defining and promoting naturalness

8 "Health Online 2013", http://www.pewinternet.org/2013/01/15/health-online-2013/last accessed on 15 May 2014. 
The distinctions and categories are purely for analytical reasons and are not mutually exclusive. We can see more than one element in the very same message; but having this distinction will help us to understand the main themes and concerns of health opinion leaders in Turkey.

The analysis of professional discourse shows us that advance of scientific knowledge in medicine brought further specializations, fields of expertise, and scientific terms and concerns specific to the field/subfields concerned. Although the knowledge and expertise is getting more and more specific, the analysis of discourses of health opinion leaders will show us that the categories and headings listed above are not mutually exclusive. In other words a health opinion leader specialized in epidemiology can talk about longevity or living a long and happy life; or you may see a cardiology expert talking about alternative medical approaches, or herbal medicine.

The first constellation of statements regarding health concerns revolves around issue of diseases. Definition and promoting of diseases is at the heart of this discourse. Health is identified with not being sick and living a healthy life with avoiding sickness. The key strategy here is to point to or create fears regarding diseases and promote available (mostly the latest) treatment. Moynihan et. al. (Moynihan, Heath, and Henry 2002:886) call this phenomenon "disease mongering": "widening the boundaries of treatable illness in order to expand markets for those who sell and deliver treatments." In this process, ordinary processes or ailments are treated as medical problems (such as baldness); or mild symptoms (such as irritable bowel syndrome) as portents of serious diseases (Moynihan et al. 2002:887). The health opinion leader warns about the risk of "obsession" in schoolchild ("Rewriting again and again may be a sign of obsession for your schoolchild. Mothers, beware of perfectionist child!"-Bengi Semerci); or states that "Erectile dysfunction is a sign of heart disease!" (irem Hattat). With the power of her and his "expertise", health opinion leader defines important health problems of our age ("Metabolic syndrome is the disease of our age. You should also protect your children, as well as yourselves!"-Aytuğ Kolankaya), introduces new categories and concerns ("There is a blood value called $\mathrm{HbA} 1 \mathrm{C}$ which shows the level of blood sugar in the last 3 months. This is important for avoiding complications related with diabetes!"-Selahattin Dönmez), and calls for necessary precautions or procedures ("If blood is seen in the excrement, the rectum must be examined for cancer: Recteoscopy or colonoscopy"-Aytuğ Kolankaya). "Control" (and "fear", as we will see below) is the key term for this paradigm. The human body is defined as a terrain being constantly attacked by diseases, viruses, potential dangers, and unhealthy substances. For living a life free from diseases, one must be constantly alerted, check her body all the time, search for abnormalities ("Thyroid gland is a crucial hormone producer. It controls your life tempo and functions. You MUST control it!"-Aytuğ Kolankaya), and take measures accordingly. The call for taking 
necessary measures may sometimes turn into bossy commands ("STAND UPRIGHT!!!"-Ender Saraç).

Defining and promoting diseases is intertwined with promoting fear. Health opinion leaders, in defining diseases also warn their followers about the risks and dangers of body. Thus, they play their role in making of society of control and fear as we have discussed above. External and internal factors and processes such as food, beverage, environment, age, household utensils, chemicals, pregnancy, or stress are evaluated as risk factors. Among these, food safety is one of the most popular subjects ("If a hazelnut tastes bitter, it is very dangerous, do not eat it, just spit it out immediately"-Murat Gökçen). ${ }^{9}$ Food and beverage that lead to cancer, and other diseases; food prepared under unhealthy conditions; food poisoning and so forth are the popular subjects that feed the health related fears ("Fats are dangerous?"-Ender Saraç). Other items such as electrical appliances we use at home, or kitchenware can be labeled as risk and fear factors ("Do electrical appliances cause cancer? 3 risks and more that kill before the age 55"-irem Hattat). The culture of fear promoted by health opinion leaders urges us to "watch out", "be careful", "check out", "beware", and always take necessary precautions (supervised and authorized by authorities of the related field), comply with necessary rules, buy necessary goods and services.

Without doubt, defining and promoting lifestyles and habits is the most recurrent theme in health opinion leaders' discourse on health. In their messages, nearly all of the opinion leaders draw the line of distinction between legitimate and illegitimate lifestyles, behaviors, and habits. Changing lifestyle and habits is the key to achieve a healthy and happy life. Eating habits and physical activity are two major concerns of the opinion leaders. Changing eating habits ("do not skip meal, skipped meals will cause further hunger, and meaningless desire to eat sugar products"-Canan Aksoy); paying attention to eating hours ("Late night snacks are an invitation to \#obesity. Beware!"-ipek Ağaca Özer); avoiding ("Avoid margarine and consume liquid oil, especially olive oil. But beware of the amount"- Aytuğ Kolankaya) or preferring ("Eat four portions of fruits per day"Aytuğ Kolankaya) specific foods, and of course, quitting smoking are the most recurrent advices regarding lifestyle. The advices of the health opinion leaders are so pervasive that they can even promise you a better life with right actions are taken ("Many people are unaware that through some small lifestyle changes they can take care of their sexual health and even prevent problems"-irem Hattat). The opinion leaders directly target body and bodily habits, and desire to recode them by promoting or demoting certain ways of eating, living, consuming -in short, certain ways of living. In order to create a disciplined, hygienic, and orderly body, changing lifestyle is a must.

9 This discourse is also in line with the introduction of food safety plan by the Ministry of Food, Agriculture, and Livestock which was introduced in 2012. As a part of plan, with regard to Law No.5996 (Foo Safety Law) 102 regulations were issued by the government. 
Defining and promoting beauty is deeply related with blurring of the line between medicine and cosmetics. This phenomena is also in accordance with commodification of medicine and medicalization of daily life. For the health opinion leader, beauty is at the same time a health issue. Healthy body is identified with a vibrant and moisturized skin; bright and dense hair; and thin and ideal measures ("omega-3 is must for a bright and younger skin"-Merve Tığlı). The health opinion leaders list factors that are detrimental to a healthy-thusbeautiful body; promotes ways to make it beautiful; and in some cases mongers some peculiar products, because for him/her "Beauty is the most powerful weapon of women" (Barış Çakır).

Living a long and quality life is another discursive theme for the health opinion leaders. This discourse constructs itself in line with the dichotomy between the young and the old. Living a long life is not enough, it must be a life in which the effects of agedness are minimized, or eliminated. In a way, it reproduces the ageist problematic which identifies youth with positive qualities such as being energetic, lively, productive, sharp and beautiful ("It's time for green tea??! Green tea protects against cancer. Makes you younger and more beautiful. Speeds your metabolism up. \#personal diet-ipek Agaca Özer); and agedness with negative ones ("YOUR WEIGHT IS YOUR AGE. For men 60$70 \mathrm{~kg}$ is young; $71-85 \mathrm{~kg}$ is between young and middle; $86-95 \mathrm{~kg}$ is middle; $96-$ $110 \mathrm{~kg}$ is above middle age-Murat Gökçen"). Illich (1976) called this "Cultural iatrogenesis", in which even death becomes a part of the medicalization of natural processes of life; and the individuals lose control over their body and pain.

Defining and promoting performance and personal development is a discursive theme related with neoliberal governmentality we have discussed above. For the health opinion leader, health is also a matter of performance and productivity. By noting that the term "performance", in the $16^{\text {th }}$ century, was a military term (accomplishing military orders and duties under given conditions), Ayanoğlu et. al (2010:43) point to the link between discourse of performance and bodily discipline. The health opinion leader defines the preconditions for living a more productive life; and by production he/she mainly refers to longer and more effective working hours. Success at life and success at work are two important objectives of human life ("People who are committed to their work, who love their job, who don't give up and more balanced are more successful and productive"-Bengi Semerci). Productivity at work is also associated with happiness found at workplace ("\#forbeinghappyattheoffice keep water in a clean bottle made of glass. Water is health..."--ipek Agaca Özer). The issue of personal development is not always centered on work-discipline. In some cases, the health opinion leader makes recommendations regarding intimate affairs such as break-ups ("10 Golden Rules after break up. www.ikimoz.com. tr-íklim Öz); mainly because happiness and pleasure are also integral elements of personal development. Accordingly, a healthy body is also a happy body, the 
body that is open to pleasures. Within this context, the health opinion leader, in some cases may prefer to act as 'agony aunt' ("Happiness is not a problem-free life; it is about the ability to cope with the problems"-Seran Göçer; "Want the best you can; do the best you can; act; and then leave yourself to the owner of this universe"-Kunter Kunt).

Naturalness is defined by some health opinion leaders as the key to a healthy, happy, long life. The stress on naturalness crosscuts many issues discussed above. Naturalness is indispensable for avoiding sickness, being beautiful, living a long life, and increasing your performance. This discourse is mostly based on promotion of consumption of natural goods ("Studies show us that kephir (yoghurt drink) is good for insomnia. You should drink a glass of kephir before going to sleep"-Murat Gökçen; "Consume rosehip as much as possible. It is good for colds. Also it is good for your bowels"-Selahattin Dönmez) or herbal treatment ("the Mediterranean diet is more useful than cholesterol pills"-Ahmet Rasim Küçükusta). The stress on natural treatment also implies a critique of pharmaceutical industry, industry of sickness, and uses and abuses of drugs ("Tıp kalpdamar hastalıklarının önlenmesinde ilaçtan daha etkili ve üstelik hiçbir yanetkisi olmayan yöntemlerin olduğunu çaresiz kabullenecek"- Ahmet Rasim Küçükusta). The stress on naturalness also points to a struggle within the field of health professionals in terms of questioning each other's approaches and methods ("Even the showmen physicians started to understand that high cholesterol is not a sickness, and cholesterol does not plug the veins"-Ahmet Rasim Küçükusta; "Like influenza vaccine, cholesterol pills are commercial products" -Ahmet Rasim Küçükusta). The health opinion leader who accuses his/her colleagues for mongering sickness and drugs, himself/herself mongers natural products, or natural treatments.

\section{Conclusion}

The analysis of health opinion leaders' social media discourse firstly points to the pervasiveness of the health concerns of the professionals, and breadth of the limits of their professional authority. The examples also show us that the limits of their authority can be so blurred, i.e. a dietician can easily discuss medical issues or give medical suggestions; or a medical doctor can tweet about some medical issue out of her/his profession. The health opinion leader, on the grounds of the privilege provided by the (somewhat blurred) scientific authority, make statements about diseases, dangers, beauty, long and quality life, naturalness, and personal development. It is such a powerful and pervasive authority that even the most intimate dimensions of human life can be object of health discourse. This is what we call medicalization of everyday life and of health. At an increasing rate, the actors of the health industry medicalize our life, and in a way colonize it. 
Although we have analyzed a small cross-section of the issue, the categories and sample statements we have discussed leads to present some general trends and recurrent themes. The health discourse of opinion leaders, mostly hold individuals responsible for protecting their health and correcting their lifestyles. This implies de-contextualization, de-socialization and depoliticization and health and health related issues. Without doubt this move is closely related to neoliberal governmentality, which promotes "enhancement of the powers of the client as customer" (Rose 1993). Accordingly, health and health related issues become exclusively problems of individuals. Within this context social, economic, political, and ecological roots of health issues are easily disregarded: pollution of air, water and soil by toxic wastes of industrial complexes; the contradiction between economic development goals and public health; unhealthy and deadly working conditions of working classes; genetically modified organisms, and so forth.

The health opinion leaders' discourse points to a world in which themes such as fear, security, hygiene, surveillance, and discipline prevail. Fear begets endless security measures, most of which requires limiting individual freedoms; hygiene and discipline rule out alternative (abnormal) engagement with bodies; disciplining bodies brings sharp divisions and hierarchies between useful and useless bodies. This is the prize that we pay for medicalization and commodification of every aspect of our lives.

\section{References}

ANGELL Marcia (2008), “Industry-Sponsored Clinical Research”, JAMA, 300(9), pp. 1069-71.

ATAAY Faruk (2006), Neoliberalizm ve Devletin Yeniden Yapılandırılması, Ankara, De Ki.

ATABEK Gülseren, ATABEK Ümit and BiLGE Deniz (2013), "Sağlık Haberlerinde Dönüşüm: 1970-2010 Yılları Arasında Hürriyet Gazetesinde Sağlık Haberleri", in Kapitalizm Sağlığa Zararlıdır, edited by Osman Elbek, İstanbul: HayyKitap, pp. 113-33.

AYANOĞLU Yıldız, ATAN Murat and BEYLIK Umut (2010), "Hastanelerde Veri Zarflama Analizi (VZA) Yöntemiyle Finansal Performans Ölçümü ve Değerlendirilmesi", Sağlıkta Performans ve Kalite Dergisi, 1(2), pp. 40-63.

BAUDRILLARD Jean (1998), The Consumer Society: Myths and Structures, London, Sage.

BAUMAN Zygmunt (2000), Modernity and the Holocaust, Cornell, Cornell University Press. 
BOTTLES Kent (2009), "Patients, Doctors and Health 2.0 Tools", PEJ, 22-25, July-August.

BOURDIEU Pierre (1996), On Television, New York, The New Press.

CANGUILHEM Georges (1991), The Normal and the Pathological, New York, Zone Books.

CASTEL Robert (1991), "From Dangerousness to Risk", in The Foucault Effect:

Studies in Governmentality, edited by Graham Burchell, Colin Gordon, and Peter Miller, Chicago, University of Chicago Press, pp. 281-98.

CHEEK Julianne (2004), "At the Margins? Discourse Analysis and Qualitative Research", Qualitative Health Research, 14(8), pp. 1140-50.

COBURN David and COBURN Elaine S (2007) "Health and Health Inequalities in a Neo-Liberal Global World", in The Economics of Health Equity, edited by Di Mclntyre and Gavin Mooney, Cambridge, Cambridge University Press, pp. 13-36.

ÇINARLI İnci (2008), Sağlık İletişimi ve Medya, Ankara, Nobel.

DELIBAŞ Kayhan (2013), "Sağlığa İlişkin Korkular: Güven Erozyonu Bağlamında Sağlık Korkularını Anlamlandırmak", in Kapitalizm Sağlığa Zararlıdır, edited by Osman Elbek. Istanbul, HayyKitap, pp. 101-13.

VAN DIJK Teun A (1989), "Structures of Discourse and Structures of Power", in Communication Yearbook 12, edited by J. A. Anderson, California, Sage, pp. 18-59.

DILLON Michael (2007), “Governing through Contingency: The Security of Biopolitical Governance", Political Geography, 26(1), pp. 41-47.

ELLIOTT Carl (2010), White Coat, Black Hat: Adventures on the Dark Side of Medicine, Boston, Beacon Press.

ERCAN Fuat (2013), "Meta Neleri İçerir? Sağlık Hizmetlerinin Metalaşması", in Kapitalizm Sağlığa Zararlıdır, edited by Osman Elbek, Istanbul, HayyKitap, pp. 15-41.

FAIRCLOUGH Norman (2001) "Critical Discourse Analysis as a Method in Social Scientific Research", in Methods of Critical Discourse Analysis, edited by Ruth Wodak and Michael Meyer, California, Sage, pp. 121-39.

FOUCAULT Michel (1977), Discipline and Punish: The Birth of Prison, New York, Vintage Books.

FOUCAULT Michel (1978), History of Sexuality Vol 1: An Introduction, New York: Pantheon Books.

FOUCAULT Michel (1981), "Omnes et Singulatim: Towards a Criticism of 'Political Reason'", in The Tanner Lectures on Human Values v. II, edited by S. McMurrin, Salt Lake City: University of Utah Press, pp. 223-54. 
FOUCAULT Michel (1982), "The Subject and Power", Critical Inquiry, 8.

FOUCAULT Michel (1991), "Governmentality", in The Foucault effect: Studies in Governmentality, vol. 14, edited by Graham Burchell, Colin Gordon, and Peter Miller, Chicago, University of Chicago Press, pp. 87-104.

FOUCAULT Michel, (2002), The Archeology of Knowledge, London and New York, Routledge.

FUREDI Frank (2002), Culture of Fear: Risk-Taking and the Morality of Low Expectation, London and New York, Continuum.

GAMBETTI, Zeynep (2012), “Foucault'tan Agamben'e Olağanüstü Halin Sıradanlığına Dair Bir Yanıt Denemesi", Cogito (70-71), pp. 1-18.

GARLAND David (2001), The Culture of Control: Crime and Social Order in Contemporary Society, Chicago, University of Chicago Press.

HALL Joanne M. (2011), "Introduction to Three Conceptual Explorations of Human Crying", Journal of holistic nursing: official journal of the American Holistic Nurses' Association, vol. 29, pp. 165-66.

HOLLIDAY Ruth and THOMPSON Graham (2001), "A Body of Work", in Contested Bodies, edited by Ruth Holliday and John Hassard, London and New York, Routledge, pp. 165-66.

HORKHEIMER Max and ADORNO Theodor W. (2002), Dialectic of Enlightenment: Philosophical Fragments, Stanford, Stanford University Press.

ILLICH Ivan (1976), Medical Nemesis: The Expropriation of Health, New York: Pantheon Books.

KART Elife (2013) "'Sağlıkta Dönüşüm' Sürecinde Performansa Dayalı Ücretlendirmenin Hekimler Üzerindeki Etkileri", Çalışma ve Toplum, 1(3), 10340.

KATZ Elihu and LAZARSFELD Paul F. (1956), Personal Influence: The Part Played by People in the Flow of Mass Communications, New Jersey, The Free Press.

KRESS Gunther R. (1989), Linguistic Processes in Sociocultural Practice, Oxford, Oxford University Press.

LUPTON Deborah (1992), "Discourse Analysis: A New Methodology for Understanding the Ideologies of Health and Illness", Australian Journal of Public Health, 16(2), pp. 145-50.

LUPTON Deborah (1999), Risk, London and New York, Routledge.

LUPTON Deborah (2003), Medicine as Culture, London, Sage.

MCGILLIVRAY David (2005a), "Fitter, Happier, More Productive: Governing Working Bodies through Wellness", Culture and Organization, 11(2), pp. 12538. 
MCGILLIVRAY David (2005b), "Governing Working Bodies Through Leisure", Leisure Sciences, 27(4), pp. 315-30.

MCINTYRE Di and MOONEY Gavin (2007), "Why This Book?" in The Economics of Health Equity, edited by Di Mclntyre and Gavin Mooney, Cambridge, Cambridge University Press, pp. 3-9.

MOONEY Gavin (2012), The Health of Nations: Towards a New Political Economy, London and New York, Zed Books.

MOYNIHAN Ray, HEATH Iona and HENRY David (2002) "Selling Sickness: The Pharmaceutical Industry and Disease Mongering", BMJ, 324(7342), pp. 886-91.

MUNCK Ronaldo (2005), "Neoliberalism and Politics, and the Politics of Neoliberalism", in Neoliberalism: A Critical Reader, edited by A. Saad-Filho and D. Johnston, London, Pluto Press, pp. 60-70.

NEUENDORF Kimberly A. (1990), "Health Images in the Mass Media", in Communication and Health: Systems and Applications, edited by Eileen Berlin Ray and Lewis Donohew, London and New York, Routledge, pp. 60-70.

NIETZSCHE Friedrich (2001), The Gay Science, Cambridge, Cambridge University Press.

PARKER Ian (1992), Discourse Dynamics: Critical Analysis for Social and Individual Psychology, London and New York, Routledge.

POWELL J. A., DARVELL, M. and GRAY J. A. M. (2003), "The Doctor, the Patient and the World-Wide Web: How the Internet Is Changing Healthcare", Journal of the Royal Society of Medicine, 96, pp. 74-76.

REINHARZ Shulamit (1997), “Enough Already! The Pervasiveness of Warnings in Everyday Life", Qualitative Sociology, 20(4), pp. 477-85.

RITZER George (2011), The McDonaldization of Society, London and New York, Sage.

ROBERTSON Ann (1998), "Shifting Discourses on Health in Canada: From Health Promotion to Population Health", Health Promotion International, 13(2), pp. 155-65.

ROSE Nikolas (1993), "Government, Authority and Expertise in Advanced Liberalism", Economy and Society, 22(3), pp. 283-99.

SEALE Clive (2002), Media and Health, London, Sage.

SEZGIN Deniz (2011), Tıbbileştirilen Yaşam Bireyselleştirilen Sağlık, Istanbul, Ayrıntı Yayınları.

TERZi Cem (2013) "Bilim, Tıp ve Kanıt", in Kapitalizm Sağlığa Zararlıdır, edited by Osman Elbek, Istanbul, HayyKitap, pp. 71-89. 
THANEM Torkild (2009), "'There's No Limit to How Much You Can Consume': The New Public Health and the Struggle to Manage Healthy Bodies", Culture and Organization, 15(1), pp. 59-74.

THOMPSON, E. P. (1993), Customs in Common: Studies in Traditional Popular Culture, New York, The New Press.

TURNER Bryan S. (1995), Medical Power and Social Knowledge, London, Sage.

TURNER Bryan S. (2002), Regulating Bodies: Essays in Medical Sociology, London and New York, Routledge.

WACQUANT Loic J. D. (1992), "Toward a Social Praxeology: The Structure and Logic of Bourdieu's Sociology", in An Invitation to Reflexive Sociology, edited by Pierre Bourdieu and Loic J. D. Wacquant, Cambridge, Polity Press, pp. 1-61.

YÜKSEL Erkan, KAYA Ahmet Yalçın, KOÇAK Abdullah and AYDIN Sinan (2014), Check Up Sağlık İletişimi, Konya: Literatürk.

ZOLA Irving Kenneth (1972), "Medicine as an Institution of Social Control", The Sociological Review, 20 (4), pp. 487-504. 